\title{
Aplikasi Google Classroom sebagai Media Pembelajaran Online dan Dampaknya Terhadap Keaktifan Belajar Siswa pada Masa Pandemi Covid-19
}

\author{
Roliana Manurung*, Arief Sadjiarto, Destri Sambara Sitorus \\ Program Studi Pendidikan Ekonomi, Universitas Kristen Satya Wacana \\ *Corresponding Author. Email: rolianamanurung80@gmail.com
}

\begin{abstract}
The objective of the current study was to analyze the google classroom app as an online learning medium and its impact on student learning activity during the covid-19 pandemic. This study applied descriptive method within qualitative approach. The research subjects were students of XI MIPA 1-3 class, economics teacher, and deputy head of the curriculum. The data collection was carried out using observation, interview, documentation and field note, then the results were analyzed using an interactive model from Miles and Hubermen which included data collection, data reduction, data display and drawing conclusion. The results of the study found that the internal factor in the online learning process using google classroom which has an impact on student learning activity is motivation. Meanwhile, student's interest in learning and readiness to learn does not have an impact on student learning activity. The external factor in the online learning process using google classroom that has an impact on learning activity is parent and teacher support. On the other hand, facilities and infrastructure have no impact on students learning activity. The google classroom app as an online learning media and its impact on student learning activity can be observed from the understanding of learning material, scores, activeness in asking questions and dicipline.
\end{abstract}

Abstrak: Penelitian ini dilakukan dengan tujuan untuk menganalisis aplikasi google classroom sebagai media pembelajaran online dan dampaknya terhadap keaktifan belajar siswa pada masa pandemi covid-19. Penelitian ini menggunakan metode deskriptif dengan pendekatan kualitatif. Subjek dalam penelitian ini yaitu siswa kelas XI MIPA 1-3, guru ekonomi, dan wakakurikulum. Teknik pengumpulan data yang digunakan adalah observasi, wawancara, dokumentasi dan catatan lapangan kemudian dianalisis menggunakan model interaktif Miles \& Hubermen yang meliputi pengumpulan data, reduksi, display data dan penarikan kesimpulan. Hasil penelitian ini menemukan bahwa faktor internal dalam proses pembelajaran online menggunakan google classroom yang memiliki dampak terhadap keaktifan belajar siswa yaitu motivasi, sedangkan minat belajar dan kesiapan belajar siswa tidak memiliki dampak terhadap keaktifan belajar siswa. Faktor eksternal dalam proses pembelajaran online menggunakan google classroom yang memiliki dampak terhadap keaktifan belajar adalah dukungan orang tua dan guru, sebaliknya sarana \& prasarna tidak memiliki dampak terhadap keaktifan belajar siswa. Aplikasi google classroom sebagai media pembelajaran online dan dampaknya terhadap keaktifan belajar siswa ini dapat diamati dari pemahaman materi, nilai, aktif bertanya dan displin.

\section{Article History}

Received: 12-05-2021

Revised: 04-07-2021

Accepted: 26-07-2021

Published: 07-09-2021

Key Words:

Google Classroom, Internal

\& External Factors,

Learning Activity.

\section{Sejarah Artikel}

Diterima: 12-05-2021

Direvisi: 04-07-2021

Disetujui: 26-07-2021

Diterbitkan: 07-09-2021

\section{Kata Kunci:}

Google Classroom,

Faktor Internal \&

Eksternal, Keaktifan

Belajar.

How to Cite: Manurung, R., Sadjiarto, A., \& Sitorus, D. (2021). Aplikasi Google Classroom sebagai Media Pembelajaran Online dan Dampaknya Terhadap Keaktifan Belajar Siswa pada Masa Pandemi Covid-19. Jurnal Kependidikan: Jurnal Hasil Penelitian dan Kajian Kepustakaan di Bidang Pendidikan, Pengajaran dan Pembelajaran, 7(3), 729-739. doi:https://doi.org/10.33394/jk.v7i3.3853 


\section{Pendahuluan}

Perkembangan teknologi informasi dan ilmu pendidikan sangat berkembang pesat setiap tahunnya, sehingga banyak menyediakan media pembelajaran secara online yang dapat dilakukan dengan memanfaatkan teknologi yang lebih baik, agar dapat meningkatkan hasil pembelajaran yang lebih efektif. Menurut Hammi (2017) menyatakan bahwa pembelajaran sekarang ini lebih diarahkan pada zaman modern dengan bantuan teknologi yang semakin canggih dengan harapan dapat membantu siswa dalam mempelajari materi pembelajaran secara efektif, interaktif, produktif dan menyenangkan dengan menggunakan media pembelajaran online yang ada.

Media yang digunakan untuk pembelajaran di era modern tidak lagi hanya berbasis offline, namun juga online. Sehingga setiap kebutuhan manusia dapat terpenuhi oleh sistem online. Media pembelajaran online di era modern menjadi unsur yang penting dalam proses pembelajaran dikarenakan guru dapat menyampaikan materi pembelajaran walaupun secara online, dan guru dapat menggunakan aplikasi media pembelajaran online yang cocok dan sesuai dengan tujuan pengajaran yang telah ditetapkan sekolah (Teni Nurrita, 2018). Banyak aplikasi yang dibuat untuk membantu dan mempermudah setiap kebutuhan manusia, termasuk di dalam dunia pendidikan. Aplikasi yang dapat digunakan secara online dapat dimanfaatkan di dalam dunia pendidikan, misalnya web sekolah maupun kampus, sistem informasi akademik, dan lain-lainnya (Asnawi, 2018). Tentu dalam hal ini merupakan hal yang baik dalam kemajuan teknologi, sehingga setiap kalangan dapat memanfaatkannya. Di masa pandemi Covid-19, Perguruan Tinggi maupun sekolah menggunakan media pembelajaran online ini disebabkan antara pendidik maupun pelajar tidak dapat melakukan kegiatan pembelajaran secara langsung.

Pembelajaran online ini lebih dikenal dengan sebutan E-Learning dimana konsep ini akan berpengaruh terhadap transformasi dunia pendidikan dari tradisional (konvensional) yang lebih menggunakan metode ceramah dan tatap muka langsung menuju ke bentuk digital (Online) baik secara sistem maupun isi atau konten (Mutia \& Leonard, 2013). E-learning juga dapat diakses dimanapun dan kapanpun oleh seluruh peserta didik selama memiliki jaringan internet (Hanum, 2013). Salah satu aplikasi yang digunakan dalam pembelajaran online ialah Google Classroom yang dapat diakses dimanapun.

Google Classroom adalah sebuah aplikasi yang memungkinkan terjadinya ruang kelas di dunia maya. Selain itu google clasroom dapat menjadi sarana distribusi tugas, submit tugas bahkan menilai tugas-tugas yang dikumpulkan (Nirfayanti, Nurbaeti, 2019). Pemanfaatan google classroom dapat digunakan melalui gadget dan laptop. Dengan menggunakan aplikasi google classroom diperkirakan bahwa tujuan pembelajaran akan lebih mudah dipahami dan diterapkan dalam pembelajaran. Oleh karena itu penggunaan google classroom ini senyatanya dapat mempermudah guru dan siswa dalam dunia maya selama masa pembelajaran daring (Hakim, 2016). Memaksimalkan aplikasi Google classroom memiliki dampak penting bagi pembelajaran di era digital, yaitu antara lain: (1) pembelajaran dengan memanfaatkan teknologi yang dilakukan secara online, 2) siswa secara langsung terlibat dalam proses pembelajaran yang memanfaatkan internet, 3) waktu dan ruang fleksibel, 4) meningkatkan keterampilan membaca data dan membaca teknologi, 5) materi pembelajaran yang diberikan oleh guru mudah di akses oleh siswa.

Selain itu, dalam pembuatan google classroom pun dapat dilakukan dengan mudah oleh guru untuk membentuk pembelajaran online menjadi lebih efisien dan efektif (Nurfalah, 2019). Aplikasi google classroom sebagai media pembelajaran secara online ini membantu siswa dalam melakukan kegiatan pembelajaran secara tidak tatap muka dalam kondisi pandemi seperti ini, sehingga siswa dapat mengirim tugas tanpa menggunakan kertas, diskusi 
online materi pembelajaran dengan guru di google classroom, dapat mendowloand file materi pembelajaran, dan melihat hasil nilai yang diberikan dosen di google classroom. Hal ini juga dirasakan oleh guru disebabkan guru dapat mendistribusikan tugas, memberikan tugas mandiri, dan dapat menilai hasil tugas-tugas yang dikerjakan siswa dirumah tanpa terikat batas waktu seperti disaat pembelajaran secara tatap muka. Sedangkan menurut Walinda (2019) di dalam penggunaan google classroom sebagai media pembelajaran online, siswa tidak hanya merasakan manfaatnya saja, akan tetapi ada beberapa kendala yang dialami salah satunya ialah siswa mengalami kesulitan dalam jaringan internet yang tidak selalu baik, dan kuota internet yang terbatas.

Dalam proses pembelajaran online menggunakan google classroom dapat diamati dari keaktifan belajar siswa tersebut dan menjadi patokan keberhasilan siswa dalam mengikuti kegiatan proses pembelajaran yang dilaksanakan. Menurut Dimiyati dan Mudjiono (2010) dalam setiap proses pembelajaran, siswa akan menampakkan keaktifan, keaktifan itu pun beraneka ragam bentuknya, mulai dari kegiatan fisik yang dapat diamati sampai kegiatan psikis yang tidak dapat diamati. Sementara menurut Yunus (2013) keaktifan belajar dipengaruhi oleh dua faktor yaitu faktor internal dan eksternal. Faktor internal merupakan faktor yang berasal dari dalam diri siswa itu sendiri, sedangkan faktor eksternal merupakan faktor yang berasal dari luar diri siswa tersebut.

Faktor internal yang ada pada siswa SMA Negeri 2 Pangkalan Bun khususnya di kelas XI MIPA 1-3 yang dapat diamati dari minat belajar, kesiapan belajar, dan motivasi. Selain itu ada juga faktor eksternal yang dapat menghambat keaktifan belajar siswa yaitu: sarana \& prasarna, dukungan orang tua, dan guru. Situasi problematika yang ada saat ini pada siswa kelas XI MIPA 1-3 yaitu seringkali siswa kurang memahami materi yang dikirim oleh guru di google classroom, kurangnya kesiapan belajar siswa sebelum pembelajaran online dilaksanakan, minat siswa terhadap pembelajaran tersebut kurang, kurangnya motivasi untuk rajin dan tekun dalam mengerjakan tugas-tugas, kurangnya kedisplinan siswa dalam mengumpulkan tugas, selain itu sering adanya gangguan jaringan internet dan tidak tersedianya kuota pada siswa di saat pembelajaran online dilaksanakan, sehingga problematika ini dapat menyebabkan proses pembelajaran online menggunakan google classroom menjadi terhambat. Namun, ada juga situasi problematika lainnya yang ada di kelas XI MIPA 1-3 ialah kurangnya dukungan dari sebagian orang tua dalam proses pembelajaran online dilaksanakan contohnya seperti orang tua mengingatkan atau membantu anaknya dalam memahami materi pembelajaran yang kurang dimengerti di dalam pembelajaran menggunakan google classroom dan guru.

Kendala spesifik yang dihadapi sekolah dalam pembelajaran online yaitu kendala didalam jaringan internet yang tidak selalu baik dalam proses pembelajaran online, selain itu ada juga siswa yang tinggal di daerah terpencil sehingga jaringan internet sulit untuk didapatkan. Kendala lainnya ialah siswa yang tidak memiliki gadget sehingga siswa terkadang meminjam handphone orang tua atau saudaranya untuk pembelajaran online. Menurut Primasari Dian N.F.I \& Zulela (2021) kendala pembelajaran jarak jauh (PJJ) selama pandemi covid 19 di sekolah dasar yaitu kurangnya ketersediaan media belajar seperti handphone, laptop atau komputer, kendala biaya untuk pembelian kouta internet, kurangnya penguasaan IPTEK dan kendala komunikasi serta sosialisasi antara siswa dan guru. Selanjutnya dalam pembelajaran online kendala yang dihadapi dalam hal penekanan pendidikan karakter ke siswa dalam hal kedisplinan siswa dalam setiap proses pembelajaran online dan tidak mudah bagi sekolah di masa pandemi Covid-19 untuk langsung berkomunikasi dengan siswa dan orang tuanya. Hal ini sejalan dengan penelitian Henry Aditia. R (2020) yang menyatakan bahwa kendala yang dihadapi guru dalam pembelajaran 
daring yaitu jaringan internet dan gawai, aplikasi pembelajaran, pendidikan karakter, pengelolaan pembelajaran, pengawasan dan penilaian.

Penelitian ini memiliki tujuan untuk menganalisis aplikasi google classroom sebagai media pembelajaran online dan dampaknya terhadap keaktifan belajar siswa di masa pandemi Covid-19. Keaktifan belajar siswa dapat diamati dari faktor internal dan eksternal. Faktor internal dan eksternal inilah yang dapat dinilai dari pemahaman materi, nilai, aktif bertanya serta disiplin yang ada didalam keaktifan belajar. Dengan menggunakan penelitian ini akan diketahui apakah aplikasi google classroom sebagai media pembelajaran online berdampak terhadap keaktifan belajar siswa pada masa pandemi Covid-19.

\section{Metode Penelitian}

Metode yang digunakan dalam penelitian ini adalah deskriptif dengan pendekatan kualitatif. Penelitian ini dilakukan di SMA Negeri 2 Pangkalan Bun, Kotawaringin Barat, Provinsi Kalimantan Tengah. Subjek penelitian ini adalah siswa-siswi XI MIPA 1-3, guru ekonomi, dan wakakurikulum SMA Negeri 2 Pangkalan Bun. Teknik pengumpulan data yang digunakan yaitu dengan observasi, wawancara secara langsung dengan siswa, guru dan wakakurikulum beserta dokumentasi. Sedangkan teknik analisis data dalam penelitian ini menggunakan model interaktif Miles \& Huberman. Penyajian data menggunakan analisis data berlangsung secara terus-menerus sampai tuntas, sehingga datanya jenuh (Sugiyono, 2013), setelah data di analisis dilakukan langkah-langkah sebagai berikut: pengumpulan data, reduksi data, display data dan penarikan kesimpulan. Teknik pemeriksaan keabsahan data dalam penelitian ini adalah triangulasi data dan menguji kredibilitas data.

\section{Hasil Penelitian dan Pembahasan}

\section{Faktor Internal pada Keaktifan Belajar Siswa dalam Proses Pembelajaran Online Menggunakan Google Classroom Minat Belajar}

Minat belajar siswa ini merupakan faktor internal yang cukup penting dalam mempengaruhi keaktifan belajar siswa. Minat belajar siswa ini muncul ketika siswa tersebut mulai menyukai atau tertarik dengan pelajaran yang dipelajari selama pembelajaran online dan akan membuat siswa menjadi aktif. Menurut Minat adalah rasa ketertarikan dan rasa lebih suka pada suatu hal kegiatan, tanpa ada yang menyuruh individu tersebut (Djaali 2008).

Berdasarkan hasil wawancara dengan siswa kelas XI MIPA 1-3 didapatkan hasil bahwa: "Untuk materi pelajaran ekonomi kayaknya belum ada materi yang saya sukai atau minat karena masih ada yang belum saya paham tentang materinya tapi saya memiliki minat atau suka terhadap penggunaan aplikasi google classroom dalam pembelajaran online ini seperti menambah wawasan saya dalam menggunakan teknologi dan lainnya"(BS).

Dari hasil wawancara diatas menjelaskan bahwa siswa tidak berminat dengan materi pelajaran ekonomi selama pembelajaran online dikarenakan siswa kurang memahami materi yang disampaikan oleh guru di google classroom. Namun dalam penggunaan aplikasi google classroom dalam pembelajaran online siswa memiliki minat atau suka disebebakan dapat menambah wawasannya dalam menggunakan teknologi. Sehingga minat belajar siswa dalam pembelajaran online menggunakan google classroom tidak memiliki minat terhadap keaktifan belajar siswa terutama didalam pemahaman materi pelajaran. Hal ini didukung dengan hasil penelitian dari Asrul dan Moh. Afil (2020) yang mengungkapkan pembelajaran daring tidak berpengaruh terhadap minat belajar siswa SMPN 1 Satap Ladongi dikarenakan siswa menjadi mudah bosan di saat pembelajaran daring dilakukan dan dalam pembelajaran 
daring kurang menarik seperti pembelajaran di kelas, selain itu kurangnya pemahaman materi dalam pembelajaran daring.

\section{Kesiapan Belajar}

Kesiapan belajar merupakan kondisi awal dalam suatu aktivitas belajar yang membuat siswa tersebut siap untuk memberi jawaban atau respon yang ada dalam dirinya sendiri agar dapat mencapai tujuan pengajaran tertentu (Hamalik, 2003). Kesiapan belajar siswa dalam menggunakan google classroom ini mendapatkan hasil dari wawancara dengan siswa kelas XI MIPA 1-3 yaitu siswa hanya mempersiapkan diri seperti bangun pagi, handphone, buku dan bolpoin sebelum diadakannya pelajaran ekonomi di google classroom.

Kesiapan belajar yang dilakukan siswa tersebut tidak memiliki dampak terhadap keaktifan belajar siswa dikarenakan kendala yang dialami siswa dalam proses pembelajaran online yaitu guru tidak memberikan info atau arahan kepada siswa mengenai materi yang akan dibahas dipertemuan selanjutnya sehingga membuat siswa menjadi tidak aktif bertanya dalam pembelajaran online dan kurang memahami materi pelajaran yang diberikan oleh guru di google classroom. Hal ini sejalan dengan hasil penelitian Wahyu Noviansyah \& Catur Mujiono (2021) yang menjelaskan kesiapan siswa SMK Kelas XI DPIB dalam mengikuti pembelajaran daring masih ditemukan kendala-kendala yang dapat menurunkan keaktifan siswa dalam belajar dan mempengaruhi keberhasilan pelaksanaan pembelajaran daring.

Siswa melakukan hal tersebut dikarenakan guru sebelum melakukan pembelajaran online di google classroom tidak memberikan info atau arahan kepada siswa mengenai materi yang akan dibahas dipertemuan selanjutnya. Namun ada juga siswa yang mencoba mencari di internet materi-materi pelajaran ekonomi buat kelas XI MIPA, dan mencatatnya. Akan tetapi materi yang didapatkan siswa tersebut tidak sesuai dengan materi yang dibahas oleh guru di pembelajaran online. Hal ini sejalan dengan hasil penelitian Wahyu Noviansyah \& Catur Mujiono (2021) yang menjelaskan kesiapan siswa SMK Kelas XI DPIB dalam mengikuti pembelajaran daring masih ditemukan kendala-kendala yang dapat menurunkan keaktifan siswa dalam belajar dan mempengaruhi keberhasilan pelaksanaan pembelajaran daring.

\section{Motivasi}

Hasil penelitian yang telah didapatkan melalui wawancara dan observasi pada narasumber siswa-siswi XI MIPA 1-3, motivasi yang selalu disampaikan guru sebelum pembelajaran dilakukan yaitu dengan kata-kata jangan patah semangat, rajin belajar, jangan lupa berdoa dan masih banyak lagi. Temuan dalam penelitian ini juga didukung oleh Dwi wahyuni (2005) motivasi belajar merupakan daya penggerak dalam melakukan aktivitas dan memberikan kekuatan untuk melakukan usaha untuk mencapai suatu tujuan. Amni, dkk (2017) menyatakan motivasi adalah salah satu faktor yang berperan penting untuk mendorong semangat belajar siswa, sehingga siswa yang mendapatkan motivasi belajar akan mudah memahami materi yang disampaikan oleh guru. Dengan demikian motivasi yang diberikan oleh guru di google classroom dapat meningkatkan semangat belajar siswa dalam mengikuti pelajaran ekonomi secara online di google classroom.

Wahyu Nuning B. (2019) menjelaskan bahwa penggunaan google classroom dapat meningkatkan motivasi belajar siswa SD dalam pelajaran Bahasa Indonesia dengan motivasi yang diberikan guru dalam pembelajaran daring. Selain itu siswa XI MIPA 1-3 mempunyai motivasi internal yang ada dalam diri sendiri. Motivasi internal tersebut dapat meningkatkan semangat belajar siswa dalam proses pembelajaran online. Sehingga motivasi ini berdampak terhadap keaktifan belajar siswa yang dapat dinilai dari displin, karena dapat membuat siswa semakin displin dalam belajar dan mengumpulkan tugas. 


\section{Faktor Eksternal pada Keaktifan Belajar Siswa dalam Proses Pembelajaran Online Menggunakan Google Classroom Sarana \& Prasarna}

Sarana \& prasarna merupakan faktor eksternal yang penting dalam pembelajaran online menggunakan google classroom. Berdasarkan hasil penelitian dengan siswa XI MIPA 1-3, guru ekonomi dan wakakurikulum sarana yang digunakan dalam pembelajaran online yaitu handphone dan laptop, sedangkan prasarna yang dipakai berupa buku paket ekonomi. Selain itu pihak sekolah juga menyediakan laptop atau komputer beserta buku-buku ekonomi bagi siswa atau guru yang tidak memiliki sarana tersebut dan guru atau siswa dapat meminjam buku-buku tersebut di perpustakaan sekolah selama masih jam sekolah.

Akan tetapi dalam pembelajaran online ini tidak hanya sarana dan prasarna saja yang menjadi pengamatan dalam penelitian ini, namun siswa juga memiliki kendala dalam hal jaringan internet yang tidak selalu baik, sedangkan kuota paket internet siswa tidak mengalami kendala, karena siswa mendapatkan bantuan paketan kuota internet dari Kemendikbud.

Sarana \& prasarna dalam pembelajaran online menggunakan google classroom tidak dapat meningkatkan keaktifan belajar siswa, dikarenakan kendala yang dihadapi siswa, guru maupun wakakurikulum yaitu jaringan internet, dimana jaringan internet ini tidak dapat diprediksi setiap saat dan tergantung dari tempat tinggalnya. Seperti halnya juga kendala yang dihadapi mahasiswa pendidikan matematika yaitu masalah jaringan internet disebabkan tempat tinggal mahasiswa ada yang didesa dan dikota yang memiliki jaringan internet yang tidak baik sehingga kurang mendukung dalam pembelajaran secara daring Agusmanto, Dkk (2020). Shobich Ulil Albab (2020) juga menjelaskan dalam penelitiannya bahwa kendala umum dalam proses pembelajaran daring di SMK Terpadu Al-Ishlahiyah yaitu kendala teknis, seperti sinyal, kuota dan perangkat yang digunakan.

\section{Dukungan Orang Tua}

Dari hasil penelitian dengan siswa-siswi XI MIPA 1-3 terdapat dukungan orang tua dalam pembelajaran online yang dilakukan melalui google classroom, yang dimana setiap orang tua siswa selalu mengingatkan untuk sekolah online, belajar, mengerjakan tugas-tugas atau PR dan dalam hal material orang tua selalu mengusahakan keperluan yang dibutuhkan anak di dalam pembelajaran online.

Azizah K.L (2020) menjelaskan bahwa tingkat peran orang tua sebagai pendidikan dalam kegiatan belajar dari rumah pada masa pandemi Covid-19 di MIN 2 Madiun termasuk dalam kategori sedang, lalu tingkat keaktifan belajar siswa dalam kegiatan belajar dari rumah juga masuk dalam kategori sedang dan terdapat pengaruh peran orang tua terhadap keaktifan belajar siswa di MIN 2 Madiun. Selain itu dukungan orang tua ini juga dikemukan oleh Siti mubarokatut darjoati isp (2020) bahwa orang tua selalu mengingatkan dan mengecek jadwal anak selama pembelajaran online. Dukungan orang tua ini memiliki dampak terhadap keaktifan belajar siswa dikarenakan semakin siswa-siswi mendapatkan dukungan orang tua, maka semakin semangat atau aktif pula dalam proses pembelajaran online menggunakan google classroom.

\section{Guru}

Guru menyampaikan materi pelajaran ekonomi dengan menggunakan video pembelajaran dari youtube, dan mengirimkan tugas disetiap pertemuan pembelajaran di google classroom hal ini didapatkan peneliti dari hasil wawancara dengan siswa XI MIPA 13 dan guru ekonomi. Di semester 1 guru juga pernah membuat simulasi berupa pertanyaan singkat di google classroom dan dapat mengacu keaktifan siswa-siswi sehingga menjawab pertanyaan singkat tersebut. Hal ini juga dikemukakan oleh Awaludin fitra, dkk (2020) guru 
SMP mengajar secara online menggunakan google classroom dengan memberikan materi didalamnya dengan membuat video pembelajaran atau mencari video pembelajaran dari youtube dan mengirimkan tugas kelas.

Dengan demikian guru ekonomi menyampaikan materi pelajaran ekonomi melalui google classroom berdampak terhadap keaktifan belajar siswa, dikarenakan cara mengajar guru ekonomi inilah yang akan meningkatkan keaktifan belajar siswa yang diamati dari pemahaman materi dan aktif bertanya. Jika guru menjelaskan secara detail atau tidak hanya dari video pembelajaran saja maka siswa akan lebih mudah memahami materi pelajaran tersebut dan akan aktif bertanya. Peneliti juga melakukan observasi langsung di google classroom tentang guru menyampaikan materi pelajaran ekonomi
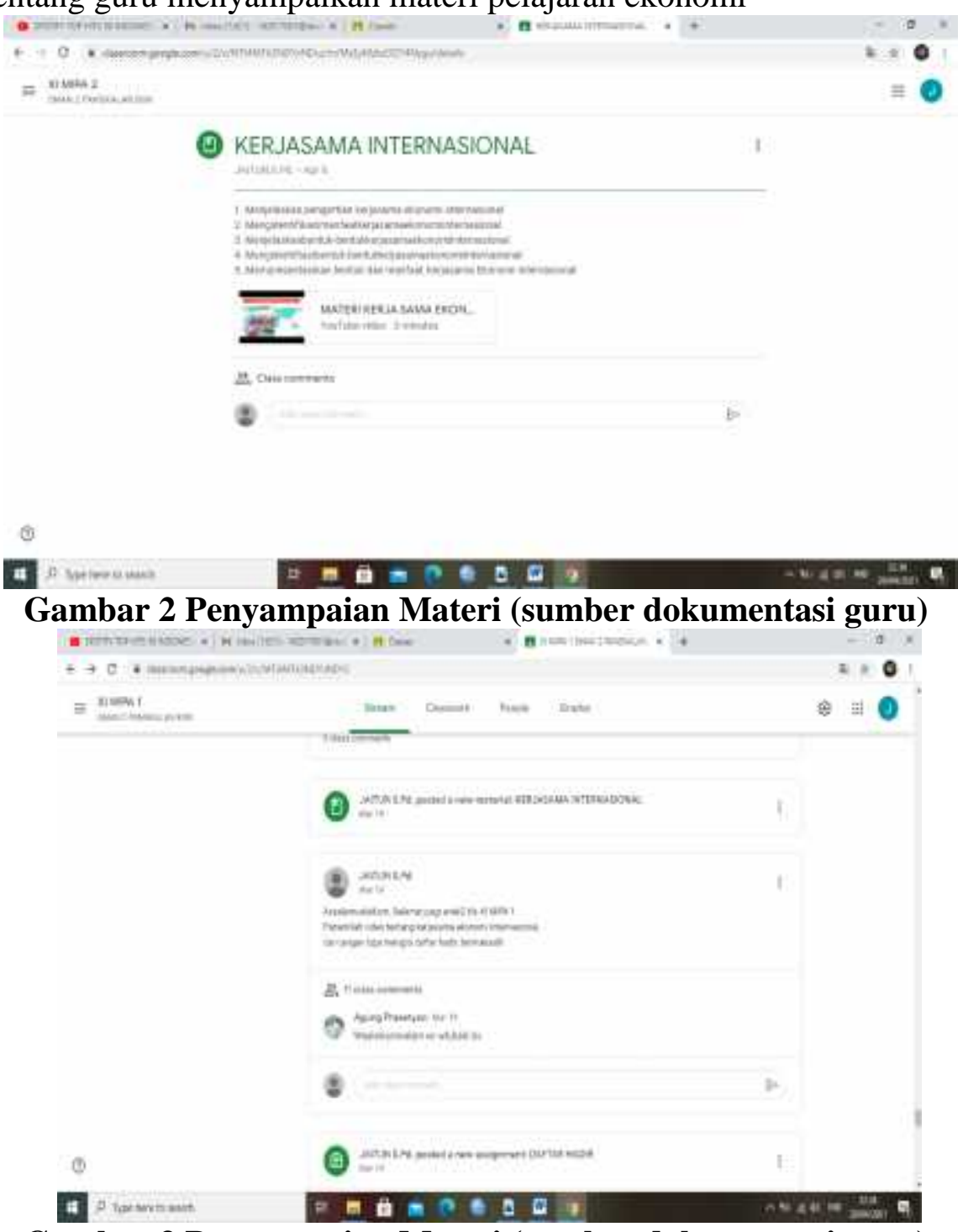

Gambar 3 Penyampaian Materi (sumber dokumentasi guru)

\section{Aplikasi Google Classroom Terhadap Keaktifan Belajar Siswa}

Aplikasi google classroom dalam pembelajaran online terhadap keaktifan belajar siswa ini dapat diamati atau dinilai dari pemahaman materi, nilai, aktif bertanya dan displin.Berdasarkan temuan penelitian ini bahwa pemahaman materi pelajaran ekonomi dalam pembelajaran online dengan menggunakan google classroom yaitu siswa-siswi dapat menonton, memahami dan membaca video pembelajaran yang di share guru di google 
classroom, dikarenakan guru akan memberikan pertanyaan atau soal berupa essay yang jawabannya ada di dalam video pembelajaran tersebut. Selain itu jika siswa masih belum memahami materi tersebut maka akan mencari materi tersebut di internet atau di youtube dengan video pembelajaran lain yang berhubungan dengan materi. Selain itu guru ekonomi juga akan meminta siswa-siswi mengulang-ngulang video pembelajaran tersebut agar tugas yang diberikan nilainya semakin bagus dan paham akan materi tersebut. Hasil penelitian ini memiliki persamaan dengan penelitian Childa Suci Wulandari, dkk (2020) bahwa kendala pembelajaran daring tidak hany bermasalah dalam teknis saja, namu dalam esensi ataupun tujuan pembelajaran belum teruji keefektifannya dalam sistem pembelajaran daring sehingga siswa ng terbiasa belajar tatap muka menjadi semakin bingung akan penjelasan materi yang disampaikan guru dalam pembelajaran daring dan dipaksa untuk paham dengan mengerjakan tugas-tugas yang ada.

Selanjutnya nilai siswa-siswi dalam pembelajaran online ini juga ada yang naik dan juga turun. Nilai siswa yang turun dikarenakan siswa tersebut belum terlalu mengerti tentang materi tersebut dan terlalu menganggap remeh dalam pembelajaran online. Sedangkan nilai siswa yang naik disebabkan karena dalam pembelajaran online bisa mencari lebih banyak info atau pengetahuan tentang materi yang disampaikan oleh guru di google classroom baik itu dari internet, youtube ataupun buku. Namun siswa juga menganggap nilai yang didapatkan selama pembelajaran online tidak sesuai dengan usaha dalam belajar. Menurut Nia Juniarti, Wanto. R (2020) menjelaskan menurunnya hasil belajar siswa-siswi SMA PGRI 02 Ella Hilir yang disebabkan oleh beberapa faktor internal dan eksternal. Berikut nilai-nilai siswa-siswi XI MIPA 1-3:

Tabel 1 Nilai Siswa-Siswi XI MIPA 1-3

\begin{tabular}{|c|c|c|c|c|}
\hline No & Nama & Kelas & $\begin{array}{c}\text { Nilai Mid } \\
\text { Semester }\end{array}$ & $\begin{array}{c}\text { Nilai } \\
\text { Semester 1 }\end{array}$ \\
\hline 1 & AN & XI MIPA 1 & 85 & 84 \\
\hline 2 & BS & XI MIPA 1 & 80 & 76 \\
\hline 3 & HAP & XI MIPA 1 & 80 & 78 \\
\hline 4 & MW & XI MIPA 1 & 84 & 82 \\
\hline 5 & ASH & XI MIPA 2 & 83 & 83 \\
\hline 6 & AT & XI MIPA 2 & 80 & 80 \\
\hline 7 & ANA & XI MIPA 2 & 85 & 83 \\
\hline 8 & WDR & XI MIPA 2 & 85 & 84 \\
\hline 9 & BS & XI MIPA 3 & 76 & 73 \\
\hline 10 & IRM & XI MIPA 3 & 85 & 82 \\
\hline 11 & STU & XI MIPA 3 & 80 & 80 \\
\hline 12 & SD & XI MIPA 3 & 79 & 72 \\
\hline \multicolumn{2}{|l}{ KKM: 73 }
\end{tabular}

Keaktifan belajar siswa juga dapat dinilai atau diamati dari siswa yang aktif bertanya selama pelajaran ekonomi dilakukan secara online. Akan tetapi siswa-siswi XI MIPA 1-3 ada yang pernah bertanya kepada guru dan ada juga yang tidak pernah. Hal ini di karenakan siswa tidak paham mengenai tugas yang diberikan dan mempunyai cukup keberanian untuk bertanya dengan guru di kolom komentar di google classroom maupun lewat whatsapp. Namun bagi siswa yang tidak pernah bertanya kepada guru dikarenakan tidak mempunyai cukup keberanian untuk bertanya dengan guru dan siswa tersebut lebih memilih bertanya kepada temannya jika memang tidak paham dengan tugas yang diberikan dan mencari di internet. Selain itu hasil penelitian dengan guru ekonomi bahwa siswa-siswi XI MIPA 1-3 
pernah bertanya mengenai tugas yang belum dipahami di google classroom maupun di whatsapp, akan tetapi aktif bertanya ini hanya berlangsung di semester 1 saja sedangkan di semester 2 ini siswa jarang bertanya kepada guru di google classroom atau whatsapp. Hasil penelitian Rono kiliadi purba (2020) menjelaskan pembelajaran jarak jauh SMA pada pelajaran ekonomi memperlihatkan adanya sikap pasif siswa dalam pembelajaran, yang menunjukan adanya masalah terhadap keaktifan siswa, seperti: siswa jarang mengajikan pertanyaan, siswa hanya berperan sebagai pendengar saja dan sangat jarang dalam menyampaikan pendapat sehingga dalam menyelesaikan masalah keaktifan siswa tersebut menggunakan metode tanya jawab.

Displin dalam keaktifan belajar juga dinilai atau diamati dalam proses pembelajaran online. Dimana setiap siswa-siswi selalu ontime dalam mengumpulkan tugas yang diberikan guru di google classroom. Tugas yang diberikan guru juga memiliki tenggang waktunya hanya 2 jam saja. Paling lambat siswa mengirimkan tugas tersebut di google classroom 1 hari. Dalam hal masuk atau absen di google classroom juga siswa jarang sekali terlambat, dikarenakan jika terlambat masuk atau absen nilainya juga akan dikurangi oleh guru. Dan keterlambatan siswa dalam masuk atau absen hanya sekitar 1 jam saja. Dengan demikian yang paling berpengaruh dalam keaktifan belajar siswa dalam proses pembelajaran online yang dapat dinilai atau diamati yaitu dari displin. Hal ini juga sejalan dengan hasil penelitian Luluk Fitriana (2020) mengungkapkan bahwa ada hubungan kedisplinan dan keaktifan belajar dengan hasil belajar IPS siswa kelas IV SDN Gugus R.A Kartini Kecamatan Dukuhseti Kabupaten Pati.

\section{Kesimpulan}

Berdasarkan hasil penelitian yang diperoleh maka dapat disimpulkan bahwa: Faktor internal dalam proses pembelajaran online menggunakan google classroom yang memiliki dampak terhadap keaktifan belajar siswa yaitu motivasi, karena motivasi internal dan yang disampaikan oleh guru membuat siswa semakin disiplin dalam belajar dan mengumpulkan tugas. Sedangkan minat belajar dan kesiapan belajar siswa tidak memiliki dampak terhadap keaktifan belajar siswa. Faktor eksternal juga memiliki dampak terhadap keaktifan belajar yaitu dengan dukungan orang tua dan guru, karena orang tua siswa-siswi selalu mengingatkan untuk sekolah online selain itu mendukung secara materiil selama proses pembelajaran online dan cara guru ekonomi mengajar dalam pembelajaran dapat meningkatkan siswa-siswi dalam aktif bertanya, sedangkan sarana \& prasarna tidak memiliki dampak terhadap keaktifan belajar siswa. Aplikasi google classroom sebagai media pembelajaran online dan dampaknya terhadap keaktifan belajar siswa ini dapat diamati atau dinilai dari pemahaman materi, nilai, aktif bertanya dan disiplin.

\section{Saran}

Saran yang disampaikan berdasarkan hasil penelitian ini adalah sebagai berikut: (1) Bagi sekolah SMA Negeri 2 Pangkalan Bun dapat meningkatkan sarana dan prasarana yang digunakan dalam pembelajaran online menggunakan aplikasi google classroom. Selain itu dapat meningkatkan pelatihan terhadap guru, agar dapat mengajar lebih baik lagi dan semakin memanfaatkan teknologi. (2) Siswa-siswi kelas XI MIPA 1-3 diharapkan melakukan kesiapan belajar dengan baik sebelum pembelajaran online dilaksanakan, selain itu mulailah menyukai atau minat dengan pembelajaran ekonomi ini agar lebih memahami materi pembelajaran dan persiapkan sarana \& prasarna dengan baik sebelum pembelajaran ekonomi dilakukan di google classsroom. (3) Bagi guru ekonomi diharapkan dapat lebih kreatif dalam setiap proses pembelajaran online yang dilaksanakan di google classroom, dengan 
menggunakan media pembelajaran tambahan lainnya contohnya zoom atau meet, sehingga siswa lebih memahami materi dan dapat menimbulkan keaktifan belajar siswa.

\section{Daftar Pustaka}

Albab, S. U. (2020). Analisis kendala pembelajaran e-learning pada era disrupsi di SMK Terpadu Al-Islahiyah Singosari Malang. Mudir: Jurnal Manajemen Pendidikan, 2(1), 47-57. http://ejournal.insud.ac.id/index.php/MPI/article/view/105

Asnawi, N. (2018). Pengukuran Usability Aplikasi Google Classroom Sebagai E-learning Menggunakan USE Questionnaire (Studi Kasus: Prodi Sistem Informasi UNIPMA). RESEARCH : Computer, Information System \& Technology Management, 1(2), 1721. https://doi.org/10.25273/research.v1i1.2451

Asrul, \& Afil, M. (2020). Dampak pembelajaran online terhadap minat belajar siswa pada masa pandemi covid-19. Publikasi Ilmiah Universitas Muhammadiyah Kendari, 1-15.

Azizah, L. K. (2020). Pengaruh Peran Orang Tua Terhadap Keaktifan Belajar Siswa pada Masa Pandemi Covid-19 di MIN 02 Madiun Kabupaten Madiun Tahun Pelajaran 2020/2021. Skripsi. Fakultas Tarbiyah dan Ilmu Keguruan IAIN Ponorogo.

Daniati, D., Ismanto, B., \& Luhsasi, D. (2020). Upaya Peningkatan Motivasi dan Hasil Belajar Mahasiswa dengan Penerapan Model Pembelajaran E-Learning Berbasis Google Classroom pada Masa Pandemi Covid-19. Jurnal Kependidikan: Jurnal Hasil Penelitian dan Kajian Kepustakaan di Bidang Pendidikan, Pengajaran dan Pembelajaran, 6(3), 601-608. doi:https://doi.org/10.33394/jk.v6i3.2642

Djaali. (2012). Psikologi pendidikan. Jakarta: Bumi Aksara

Endang. (2020). Model pembelajaran mastery learning upaya peningkatan keaktifan dan hasil belajar siswa. CV Budi Utama: Yogyakarta

Fauziah et al., (2017). Hubungan Antara Motivasi Belajar Dengan Minat Belajar Siswa Kelas IV SDN Poris Gaga 05 Kota Tangerang. Jurnal JPSD, 4(2). 48-53. DOI: http://dx.doi.org/10.26555/jpsd

Fernández et al., (2020). Peran orang tua sebagai guru di rumah pada pembelajaran daring di SD Negeri Kebonromo 3 Sragen selama pandemi covid 19. Publikasi Ilmiah. Universitas Muhammadiyah Surakarta.

Fitra, A., Sitorus, M., Parulian Sinaga, D. C., \& Marpaung, E. A. P. (2020). Pemanfaatan dan Pengelolaan Google Classroom Sebagai Media Pembelajaran Dan Pengajaran Daring Bagi Guru-Guru SMP. Jurnal Pengabdi, 3(2), 101-109. https://doi.org/10.26418/jplp2km.v3i2.42387

Hakim, A. B. (2016). Efektifitas Penggunaan E-Learning Moodle , Google Classroom Dan Edmodo. Jurnal I-Statement, 2(1), 1-6.

Hammi, Z. (2017). "Implementasi Google Classroom Pada Kelas XI IPA Man 2 Kudus." Skripsi, 1-58. https://lib.unnes.ac.id/31039/

Hutauruk, A., \& Sidabutar, R. (2020). Kendala Pembelajaran Daring Selama Masa Pandemi di Kalangan Mahasiswa Pendidikan Matematika: Kajian Kualiatatif Deskriptif. SEPREN: Journal of Mathematics Education and Applied, 2(1), 45-51. https://doi.org/10.36655/sepren.v2i1.364

Leonard. (2013). Kajian Penerapan E-Learning Dalam Proses. Faktor Exacta, 6(4), 278-289. https://journal.lppmunindra.ac.id/index.php/Faktor_Exacta/article/download/239/22

Moleong. (2010). Metodologi penelitian kualitatif. Bandung: PT Remaja Rosdakarya.

Mudjino. (2010). Belajar dan pembelajaran. Jakarta: Rineka cipta. 
Mustaniroh, S. A. (2015). Penerapan Google Classroom Sebagai Media Pembelajaran Pada Pelajaran Kimia di SMK Negeri 2 Temanggung. Artikel Ilmiah. Fakultas Teknologi Informasi Universitas Kristen Satya Wacana.

Naziaha, S. T., Maula, L. H., \& Sutisnawati, A. (2020). Analisis Keaktifan Belajar Siswa Selama Pembelajaran Daring Pada Masa Covid-19 Di Sekolah Dasar. Jurnal Paedagogy: Jurnal Penelitian Dan Pengembangan Pendidikan, 7(2), 109-120. DOI: http://dx.doi.org/10.26555/jpsd

Nirfayanti, N., \& Nurbaeti, N. (2019). Pengaruh Media Pembelajaran Google Classroom Dalam Pembelajaran Analisis Real Terhadap Motivasi Belajar Mahasiswa. Proximal Jurnal Penelitian Matematika Dan Pendidikan Matematika, 2(1), 50-59. https://ejournal.my.id/proximal/article/view/211

Noviansyah, W., \& Mujiono, C. (2021). Analisis Kesiapan dan Hambatan Siswa SMK dalam Menghadapi Pembelajaran Daring di Masa Pandemi. Jurnal Studi Guru Dan Pembelajaran Universitas Sebelas Maret, Indonesia, 4(1), 82-88.

Nurfalah, E. (2019). Optimalisasi E-Learning berbasis Virtual Class dengan Google Classroom sebagai Media Pembelajaran Fisika. Physics Education Research Journal, 1(1), 46-55. https://doi.org/10.21580/perj.2019.1.1.3977

Nurrita, T. (2018). Pengembangan Media Pembelajaran Untuk Meningkatkan Hasil Belajar Siswa. MISYKAT: Jurnal Ilmu-Ilmu Al-Quran, Hadist, Syari'ah Dan Tarbiyah, 3(1), 171-187. https://doi.org/10.33511/misykat.v3n1.171

Primasari Dian, N. F. I \& Zulela (2021). Kendala Pembelajaran Jarak Jauh (PJJ) Secara Online Selama Masa Pandemik Covid-19 di Sekolah Dasar. Jurnal Ilmiah Ilmu Kependidikan PGSD, 5(1), 64-73.

Riswani, E. F., \& Widayati, A. (2012). Model Active Learning Dengan Teknik Learning Starts With a Question Dalam Peningkatan Keaktifan Peserta Didik Pada Pembelajaran Akuntansi Kelas Xi Ilmu Sosial 1 Sma Negeri 7 Yogyakarta Tahun Ajaran 2011/2012. Jurnal Pendidikan Akuntansi Indonesia, 10(2), 1-21. https://doi.org/10.21831/jpai.v10i2.910

Slameto. (2010). Belajar dan Faktor - faktor yang Mempengaruhinya. Jakarta: PT Rineka Cipta.

Sugiyono. (2013). Metode Penelitian Kualitatif, Kuantitatif, dan R\&D. Bandung: Alfabeta.

Wahyuni. (2005). Pengaruh Kesiapan Belajar, Motivasi Belajar Dan Pengulangan Materi Pelajaran Terhadap Hasil Belajar Mata Pelajaran Ekonomi Pada Siswa Kelas II Ma Al Asror Gunung Pati Tahun Pelajaran 2004/2005. Skripsi. Universitas Negeri Semarang

Yulfianti, S., \& Dewi, R. (2021). Efek Learning Management System Berbasis Google Classroom dan Minat Belajar Terhadap Hasil Belajar Ekonomi Siswa. Jurnal Kependidikan: Jurnal Hasil Penelitian dan Kajian Kepustakaan di Bidang Pendidikan, Pengajaran dan Pembelajaran, 7(2), 491-502. doi:https://doi.org/10.33394/jk.v7i2.3717

Yunus et al., (2013). Pengaruh pemberian motivasi belajar oleh guru terhadap prestasi belajar siswa pada mata pelajaran IPS di SMP NU 01 hasyim asy'ari taruh tahun pelajaran 2012-2013. Jurnal pendidikan ekonomi, 8(1), 1-21. 